\title{
Hubungan Faktor Lingkungan dengan Kejadian Diare Balita di Wilayah Kerja Puskesmas Kambang Kecamatan Lengayang Kabupaten Pesisir Selatan Tahun 2013
}

\author{
Fitra Dini ${ }^{1}$, Rizanda Machmud ${ }^{2}$, Roslaili Rasyid ${ }^{3}$
}

\begin{abstract}
Abstrak
Puskesmas Kambang adalah kejadian diare terbanyak di Pesisir Selatan yang menjadi insiden tertinggi di Sumatera Barat tahun 2012 dengan kondisi sanitasi yang sehat kurang dari 60\%. Hampir sepertiga kasusnnya terjadi pada balita $(26,7 \%)$. Tujuan penelitian adalah untuk mengetahui hubungan faktor lingkungan dengan kejadian diare balita. Penelitian menggunakan desain analitik cross sectional dengan jumlah subjek 63 orang dengan teknik multi stage random sampling. Penelitian menggunakan kuesioner melalui wawancara dan observasi. Hasil penelitian didapatkan analisis univariat kejadian diare balita 36 (57,1\%), pembuangan tinja yang tidak sehat 34 (54\%), sumber air minum tidak sehat 30 (47,6\%), SPAL RT yang buruk 40 (63,5\%), pengelolaan sampah yang buruk 36 (57,1\%). Analisis bivariat didapatkan hasil ada hubungan signifikan antara pembuangan tinja dengan kejadian diare balita $(p=0,010), O R=4,5$. Ada hubungan signifikan antara sumber air minum dengan kejadian diare balita $(p=0,026)$, $\mathrm{OR}=3,7$. Ada hubungan yang signifikan antara SPAL RT dengan kejadian diare balita $(p=0,003), O R=6$. Ada hubungan yang signifikan antara pengelolaan sampah dengan kejadian diare balita $(p=0,043), O R=3,3$. Kesimpulan adalah ada hubungan yang signifikan antara faktor lingkungan.
\end{abstract}

Kata kunci: diare, balita, faktor lingkungan

\begin{abstract}
Kambang Health Center has the highest incidence of diarrhea in the South Pesisir which became the highest incidence in West Sumatra in 2012 with healthy sanitary conditions of less than 60\%. Nearly one-third of cases occur in children under five (26.7\%). The objective of this study was to determine the relationship of environmental factors with the incidence of diarrhea in children under five. This study used a cross sectional analytic method with a total subjek were 63 people, chosen by multistage random sampling technique. This study also used a questionnaire with interviewed and observation. Univariate analysis results showed that the incidence of diarrhea children under five 36 (57.1\%), unsanitary excreta disposal 34 (54\%), the source of drinking water is not healthy 30 (47.6\%), poor waste water drainage system 40 (63.5\%), poor waste management 36 (57.1\%). Bivariate analysis showed significant relationship between excreta disposal site with the incidence of diarrhea in children under five with $p=0.010$ and $O R=4.5$. There is a significant relationship between sources of drinking water with the incidence of diarrhea in children under five with $p=0.026$ and $O R=3.7$. There is a significant relationship between the waste water drainage system with the incidence of diarrhea in children under five with $p=0.003$ and $O R=6$. There is a significant relationship between waste management with the incidence of diarrhea in children under five with $p=0.043$ and $O R=3.3$. In conclusion, there were significant relationship between environmental factors.
\end{abstract}

Keywords: diarrhea, children under five, environmental factors

Affiliasi penulis : 1. Pendidikan Dokter FK UNAND, 2. Bagian IImu Kesehatan Masyarakat FK UNAND, 3. Bagian Mikrobiologi FK UNAND Korespondensi : Fitra Dini, E-mail:dy_fitra@yahoo.com, Telp: 085263656790

\section{PENDAHULUAN}

Masalah kesehatan merupakan masalah yang sangat kompleks terkait dengan masalah kesehatan 
lingkungan maupun kesehatan individu. Kesehatan lingkungan pada hakikatnya adalah suatu kondisi atau keadaan lingkungan yang optimum sehingga berpengaruh positif terhadap terwujudnya kesehatan yang optimum pula.

Salah satu penyakit yang terkait dengan tingkat derajat kesehatan tersebut adalah diare. Kejadian diare pada umumnya terjadi pada negara berkembang dengan kondisi sanitasi lingkungan yang buruk, persediaan air yang tidak adekuat, kemiskinan dan pendidikan yang terbatas. ${ }^{2}$ Indonesia sebagai salah satu negara berkembang, menurut survei morbiditas diare tahun 2010 yang dilakukan oleh Subdit Diare, Departemen Kesehatan, insiden diare di Indonesia tahun 2000-2010 cenderung naik. Pada tahun 2000, angka kejadian diare adalah 301/1000 penduduk, tahun 2003 terdapat peningkatan menjadi 374/1000 penduduk, tahun 2006 naik menjadi 423/1000 penduduk dan tahun 2010 terdapat penurunan menjadi 411/1000 penduduk. Meskipun angka kejadian diare menurun pada tahun 2010, hal tersebut tidak menunjukkan penurunan yang signifikan. ${ }^{3}$

Berdasarkan jenis penyakit pada tahun 2012, diare termasuk salah satu penyakit menular tertinggi di Sumatera Barat dengan jumlah 83.375 kasus dan diantara kasus tersebut 11.139 kasus terjadi di Kabupaten Pesisir Selatan yang merupakan insiden tertinggi di Sumatera Barat. ${ }^{4}$ Tahun 2012, di kabupaten Pesisir Selatan juga merupakan wilayah kasus diare terbanyak yang ditangani di Sumatera Barat yaitu 12.935 kasus (72,6\%) dengan angka kejadian $31,3 / 1000$ penduduk. ${ }^{4,5}$

Balita adalah kelompok umur yang rentan terhadap penyakit karena sistem imun yang masih lemah sehingga mudah terserang infeksi bakteri, virus maupun parasit. Pada umumnya, insiden tertinggi diare terjadi pada satu dan dua tahun kehidupan yang diikuti penurunan dengan bertambahnya umur. Setiap tahun dapat diperkirakan 2,5 miliar kasus diare terjadi pada anak umur di bawah lima tahun. ${ }^{6}$ Diare adalah penyebab ke-2 kematian pada anak di bawah lima tahun dengan jumlah kematian sekitar 760.000 anak tiap tahunnya. Di Indonesia, diare adalah salah satu penyakit infeksi tropis pada balita dengan prevalensi 16,7 persen dari semua kejadian diare dan menjadi penyebab utama kematian balita $25,2 \% .^{7}$ Oleh karena itu, perlu tatalaksana lebih lanjut sesuai target MDG's (Milenium Development Goals) ke-4 adalah penurunan kematian anak dari tahun 1990 sampai 2015 menjadi 2/3 bagian, salah satu upaya yang dilakukan adalah menurunkan kematian karena diare melalui pencegahan faktor risiko terjadinya diare. ${ }^{3}$

Diare merupakan salah satu penyakit yang berbasis lingkungan. Apabila faktor lingkungan tidak sehat yang tercemar kuman diare berakumulasi dengan perilaku manusia yang tidak sehat maka akan menimbulkan kejadian diare balita yang ditularkan melalui makanan dan minuman. ${ }^{8}$ Bagian yang terpenting dalam upaya pencegahan dan penanggulangan diare tersebut adalah dengan cara memutus rantai penularan yang menitikberatkan kepada penanggulangan faktor risiko penyakit salah satunya sanitasi lingkungan yang tidak higiene. ${ }^{9}$

Faktor lingkungan yang dominan seperti pembuangan tinja dan sumber air minum, berperan dalam penyebaran kuman diare pada balita. ${ }^{8}$ Pengalaman beberapa negara membuktikan upaya penggunaan jamban sebagai tempat pembuangan tinja mempunyai dampak yang besar terhadap penurunan risiko penyakit diare. ${ }^{10}$ Sarana air minum juga merupakan bagian yang terpenting dalam kesehatan lingkungan. Semua sumber air minum harus memenuhi syarat kesehatan air minum karena sangat erat kaitannya dengan penyakit diare. Pembuangan air limbah RT juga berkontribusi pada sanitasi lingkungan.

Halaman rumah yang becek karena buruknya Saluran Pembuangan Air Limbah (SPAL) memudahkan penularan penyakit diare balita terutama yang ditularkan oleh cacing dan parasit. ${ }^{9}$ Limbah padat seperti sampah juga merupakan media yang baik untuk berkembangbiaknya vektor penyakit. ${ }^{10}$

Data laporan bidang P2B \& PL Dinas Kesehatan Kabupaten Pesisir Selatan menunjukkan bahwa Puskesmas Kambang adalah salah satu dari 18 puskesmas yang berada di Kabupaten Pesisir Selatan dengan insiden diare terbanyak ditangani tahun 2012. Jumlah diare yang ditangani di Puskesmas Kambang tahun 2012 adalah 1.257 kasus atau 9,7\% dari total kejadian diare di Kabupaten Pesisir Selatan. Kejadian diare pada balita adalah 336 kasus $(26,7 \%)$. Hal 
tersebut menunjukkan hampir sepertiga dari jumlah kejadian diare di Puskesmas Kambang terjadi pada umur balita. ${ }^{5,11}$

Berdasarkan profil laporan tahunan Puskesmas Kambang, di Kecamatan Lengayang tahun 2012, beberapa aspek sanitasi lingkungan seperti jamban, sarana air minum, SPAL dan pengelolaan sampah yang sehat kurang dari $60 \%$. Berdasarkan data tersebut, diantaranya masih ada penduduk yang membuang tinja sembarangan akibat tidak tersedianya jamban keluarga.Selain itu, penduduk di wilayah kerja Puskesmas Kambang sebagian besar mendapatkan sarana air minum dari air sumur gali yang kemungkinan cenderung terkontaminasi. Data laporan Puskesmas Kambang, penduduk disana juga bermasalah dengan SPAL dan sampah. SPAL dan pengelolaan sampah yang tidak memenuhi syarat sanitasi kesehatan merupakan media yang baik sebagai reservoir bibit penyakit. $^{11}$

Tujuan penelitian ini adalah mengetahui gambaran distribusi kejadian diare balita, pembuangan tinja, sumber air minum, SPAL rumah tangga, pengelolaan sampah serta hubungan faktor lingkungan (pembuangan tinja, sumber air minum, SPAL RT, pengelolaan sampah) terhadap kejadian diare balita.

\section{METODE}

Penelitian menggunakan rancangan penelitian survey analitik cross sectional yaitu melakukan observasi terhadap variabel dependen maupun independen yang kemudian dilakukan suatu analisis variabel dengan membandingkan faktor risiko (variabel independen) terhadap faktor efek (variabel dependen) pada saat atau periode yang sama. ${ }^{12}$ Populasi penelitian adalah Ibu yang mempunyai balita umur (1-5 tahun) bertempat tinggal di wilayah kerja Puskesmas Kambang, Kecamatan Lengayang, Kabupaten Pesisir Selatan dengan jumlah 63 orang yg diambil dengan teknik multistagerandom sampling. Penelitian ini menggunakan kuesioner dengan cara wawancara dan observasi langsung. Variabel yang diteliti adalah kejadian diare balita dan faktor lingkungan seperti pembuangan tinja, sumber air minum, SPAL rumah tangga dan pengelolaan sampah dengan analisis univariat dan bivariat menggunakan uji chi square.
HASIL

A. Analisis Univariat

1. Gambaran Kejadian Diare Balita

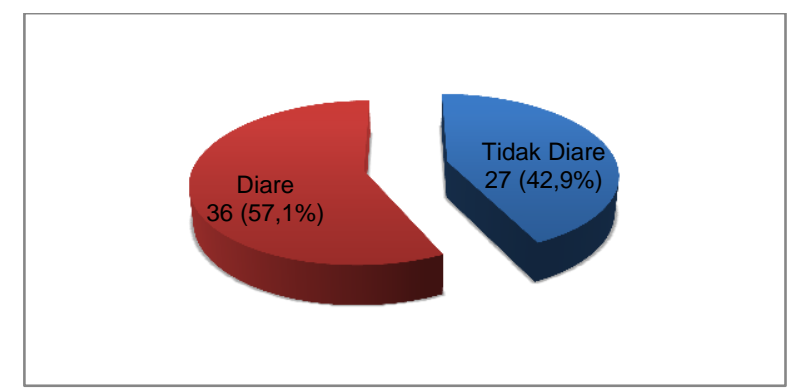

Gambar 1. Gambaran kejadian diare balita di wilayah kerja Puskesmas Kambang Kecamatan Lengayang Kabupaten Pesisir Selatan tahun 2013

Berdasarkan Gambar 1 hasil wawancara penelitian didapatkan bahwa balita yang mengalami kejadian diare $(57,1 \%)$.

\section{Faktor Lingkungan}

Tabel 1. Distribusi faktor lingkungan di wilayah kerja Puskesmas Kambang Kecamatan Lengayang Kabupaten Pesisir Selatan tahun 2013

\begin{tabular}{|c|c|c|c|}
\hline No & Faktor Lingkungan & Frekuensi & $\%$ \\
\hline \multirow[t]{4}{*}{1.} & Pembuangan Tinja & & \\
\hline & Tidak Sehat & 34 & 54,0 \\
\hline & Sehat & 29 & 46,0 \\
\hline & Jumlah & 63 & 100 \\
\hline \multirow[t]{4}{*}{2.} & Sumber Air Minum & & \\
\hline & Tidak Sehat & 30 & 47,6 \\
\hline & Sehat & 33 & 52,4 \\
\hline & Jumlah & 63 & 100 \\
\hline \multirow[t]{4}{*}{3.} & SPAL RT & & \\
\hline & Buruk & 40 & 63,5 \\
\hline & Baik & 23 & 36,5 \\
\hline & Jumlah & 62 & \\
\hline \multirow[t]{4}{*}{4.} & Pengelolaan Sampah & & \\
\hline & Buruk & 36 & 57,1 \\
\hline & Baik & 27 & 42,9 \\
\hline & Jumlah & 63 & 100 \\
\hline
\end{tabular}

Berdasarkan hasil analisis univariat dapat dinilai bahwa pembungan tinja yang tidak sehat adalah 54\%, sumber air tidak sehat $47,6 \%$, SPAL RT yang buruk $63,5 \%$, pengelolaan sampah yang buruk $57,1 \%$. Hal ini menunjukkan bahwa rerata lebih 50\% wilayah kerja Puskesmas Kambang masih mempunyai masalah terhadap lingkungan yang belum memenuhi syarat 
sanitasi lingkungan yang sehat.

\section{B. Analisis Bivariat}

Tabel 2. Hubungan faktor lingkungan dengan kejadian diare balita di wilayah kerja Puskesmas Kambang Kecamatan Lengayang Kabupaten Pesisir Selatan tahun 2013

\begin{tabular}{|c|c|c|c|c|c|c|c|c|}
\hline \multirow[t]{2}{*}{$\begin{array}{c}\text { Faktor } \\
\text { Lingkungan }\end{array}$} & \multicolumn{2}{|c|}{ Diare } & \multicolumn{2}{|c|}{$\begin{array}{l}\text { Tidak } \\
\text { Diare }\end{array}$} & \multicolumn{2}{|c|}{$\begin{array}{c}\text { Jumlah } \\
\text { ( N ) }\end{array}$} & \multirow{2}{*}{$\begin{array}{c}\text { OR } \\
95 \% \\
\mathrm{Cl}\end{array}$} & \multirow[t]{2}{*}{$\mathbf{P}$} \\
\hline & $f$ & $\%$ & $f$ & $\%$ & $f$ & $\%$ & & \\
\hline \multicolumn{9}{|l|}{$\begin{array}{c}\text { Pembua } \\
\text { ngan Tinja }\end{array}$} \\
\hline Tidak Sehat & 25 & 73,5 & 9 & 26,5 & 34 & 100 & 4,5 & 0.010 \\
\hline Sehat & 11 & 37,9 & 18 & 62,1 & 29 & 100 & $\begin{array}{l}(1,6- \\
13,2)\end{array}$ & \\
\hline \multicolumn{9}{|l|}{ SAM } \\
\hline Tidak Sehat & 22 & 73,3 & 8 & 26,7 & 30 & 100 & 3,7 & 0,026 \\
\hline Sehat & 14 & 42,4 & 19 & 57,6 & 33 & 100 & $\begin{array}{l}(1,3- \\
10,8)\end{array}$ & \\
\hline Jumlah & 36 & 57,1 & 27 & 42,9 & 63 & 100 & & \\
\hline \multicolumn{9}{|l|}{ SPAL RT } \\
\hline Buruk & 29 & 72,5 & 11 & 27,5 & 40 & 100 & 6 & 0,003 \\
\hline Baik & 7 & 30,4 & 16 & 69,6 & 23 & 100 & $\begin{array}{l}(1,95- \\
18-6)\end{array}$ & \\
\hline Jumlah & 36 & 57,1 & 27 & 42,9 & 63 & 100 & & \\
\hline \multicolumn{9}{|l|}{ Pengelolaan } \\
\hline \multicolumn{9}{|l|}{ Sampah } \\
\hline Buruk & 25 & 69,4 & 11 & 30,6 & 36 & 100 & 3,3 & 0,043 \\
\hline Baik & 11 & 40,7 & 16 & 59,3 & 27 & 100 & $\begin{array}{l}(1,2- \\
9,4)\end{array}$ & \\
\hline Jumlah & 36 & 57,1 & 27 & 42,9 & 63 & 100 & & \\
\hline
\end{tabular}

Berdasarkan Tabel 2 dapat diketahui bahwa proporsi kejadian diare balita lebih tinggi pada pembuangan tinja yang tidak sehat 25 (73,5\%) dibandingkan dengan pembuangan tinja yang sehat 11 (37,9\%). Hasil uji statistik dengan chi-square didapatkanp $=0.010(p<0,05)$ yang dapat disimpulkan ada hubungan yang signifikan antara pembuangan tinja dengan kejadian diare balita, OR $=4,5$ dan $95 \% \mathrm{Cl}$ $(1,6-13,2)$ artinya sumber air minum merupakan faktor risiko terjadinya diare balita. Responden dengan sumber air minum yang tidak sehat mempunyai risiko 3,7 kali mengalami kejadian diare balita dibandingkan responden dengan sumber air minum yang sehat.

Pada sumber air minum, proporsi kejadian diare balita lebih tinggi pada sumber air minum yang tidak sehat $22(73,3 \%)$ dibandingkan sumber air minum yang sehat $14(42,4 \%)$. Hasil uji statitistik dengan chi-square didapatkani $p=0,026(p<0,05)$ yang dapat disimpulkan ada hubungan yang signifikan antara sumber air minum dengan kejadian diare balita. Hasil analisis menunjukkan nilai $\mathrm{OR}=3,7$ dan $95 \% \mathrm{Cl}(1,3-10,8)$ artinya sumber air minum merupakan faktor risiko terjadinya diare balita. Responden dengan sumber air minum yang tidak sehat mempunyai risiko 3,7 kali mengalami kejadian diare balita dibandingkan responden dengan sumber air minum yang sehat.

Proporsi kejadian diare balita lebih tinggi pada saluran pembuangan air limbah rumah tangga yang buruk $29(72,5 \%)$ dibandingkan saluran pembuangan air limbah rumah tangga yang baik 7 (30,4\%). Hasil uj statistik chi square didapatkan $p=0,003(p<0,05)$ yang dapat disimpulkan ada hubungan yang signifikan antara saluran pembuangan air limbah rumah tangga (SPAL RT) dengan kejadian diare balita Hasil analisis menunjukkan nilai OR $=6$ dan 95\% Cl $(1,95-18,6)$ artinya saluran pembuangan air limbah RT merupakan faktor risiko terjadinya diare balita. Responden dengan SPAL yang buruk mempunyai risiko 6 kali mengalami kejadian diare balita dibandingkan responden dengan SPAL yang baik.

Proporsi kejadian diare balita lebih tinggi pada pengelolaan sampah yang buruk 25 (69,4\%) dibandingkan pengelolaan sampah yang baik 11 (40,7\%). Hasil uji statistik dengan chi square didapatkan $\mathrm{p}=0,043(\mathrm{p}<0,05)$ yang dapat disimpulkan ada hubungan yang signifikan antara pengelolaan sampah dengan kejadian diare balita Hasil analisis menunjukkan nilai $\mathrm{OR}=3,3$ dan $95 \% \mathrm{Cl}(1,2-9,4)$ artinya pengelolaan sampah merupakan faktor risiko terjadinya diare balita. Responden dengan pengelolaan sampah yang buruk mempunyai risiko 3,3 kali mengalami kejadian diare balita dibandingkan responden dengan pengelolaan sampah yang baik.

\section{PEMBAHASAN}

\section{Distribusi Kejadian Diare Balita}

Berdasarkan hasil penelitian dapat dilihat bahwa $57,1 \%$ balita menderita diare. Menurut data tersebut, lebih dari setengah responden menyatakan balitanya pernah mengalami diare dalam 3 bulan terakhir. Hasil penelitian Octorina tahun 2012 bahwa jumlah balita yang mengalami diare di Desa Sialang Buah, Kecamatan Teluk Mengkudu adalah 45 (51,1\%), artinya lebih dari setengah responden yang diteliti rerata balitanya menderita diare. ${ }^{13}$ Hasil yang sama juga 
didapatkan oleh penelitian Umiati tahun 2010 di wilayah kerja Puskesmas Nogosari, Kabupaten Boyolali dengan kejadian diare balita yaitu $43(71,7 \%)$ dari 60 responden yang diteliti. ${ }^{14}$ Hasil tersebut menunjukkan masih banyak kejadian diare balita tersebar disetiap wilayah.

\section{Distribusi Faktor Lingkungan}

Berdasarkan hasil penelitian didapatkan 34 (54,0\%) responden mempunyai masalah dalam pembuangan tinja yang dikategorikan sebagai pembuangan tinja yang tidak sehat. ini disebabkan kebiasaan dan lokasi pembuangan tinja yang tidak memenuhi syarat karena tidak tersedianya jamban keluarga sehingga harus membuang tinja di parit, sungai bahkan ada di belakang rumah dengan cara di timbun dengan tanah. Beberapa jamban ditemukan dalam keadaan tidak tertutup dan tidak bersih yang memungkinkan untuk berkembangbiaknya bibit penyakit. Penelitian ini sejalan dengan penelitian Amaliah tahun 2010 di desa Toriyo, Kecamatan Bendoyo, Kabupaten Sukoharo yaitu dari 68 responden yang diteliti terdapat $37(54,42 \%)$ rumah yang tidak memiliki jamban. ${ }^{14}$

Penelitian yang mirip juga terdapat pada Novytania tahun 2013 di Kecamatan Kabuh, Kabupaten Jombang bahwa terdapat 21 (42,8\%) responden yang tidak memiliki jamban, $28,6 \%$ memiliki jamban tanpa tanki septik dan sisanya kurang dari sepertiga jumlah responden $(28,6 \%)$ yang memiliki jamban dengan tanki septik atau jamban leher angsa. ${ }^{15}$

Hasil penelitian mendapatkan sumber air minum yang tidak sehat adalah 30 (47,6\%). Air minum yang tidak sehat tersebut dipengaruhi oleh sumber air, kualitas fisik air dan jarak sumber air dari pencemaran terutama pada air sumur gali. Sebagian besar responden menggunakan air sumur gali sebagai sumber air minum. Beberapa responden ada yang memanfaatkan Perusahaan Daerah Air Minum dan air isi ulang atau air botol kemasan untuk konsumsi seharihari. Keadaan sumur pada umumnya tidak terlindung dengan jarak kurang dari 10 meter dari sumber pencemaran.

Pada umumnya air minum yang digunakan oleh penduduk secara kualitas fisik dapat dinilai baik dan relatif aman yaitu $<50 \%$, tetapi beberapa responden mempunyai sumber air minum yang bermasalah terutama penduduk yang memanfaatkan air sumur gali tidak terlindung. Keluarga yang menggunakan sumur gali tidak terlindung dengan bentuk konstruksi yang tidak memiliki cincin dan sangat dekat dari sumber pencemaran seperti tempat pembuangan air limbah, sampah dan kandang ternak memberikan pengaruh terhadap kualitas fisik air baik dari segi warna, kejernihan, rasa dan bau yang merupakan factor sebagai sumber air minum yang tidak sehat.

Berdasarkan hasil wawancara dan observasi terhadap didapatkan hasil bahwa sebagian besar responden 40 (63,5\%) memiliki SPAL RT yang buruk. Hal tersebut dapat dilihat dari 63 responden yang diteliti $18(28,6 \%)$ responden tidak memiliki SPAL dan 22 $(48,9 \%)$ responden memiliki SPAL yang terbuka dengan kondisi saluran pembuangan air limbah RT yang belum memenuhi syarat sanitasi seperti adanya air yang tergenang di sekitar rumah, menimbulkan bau yang tidak enak dan terdapat berbagai vektor penyakit seperti kecoa dan tikus. Penelitian ini mirip dengan penelitian Octorina tahun 2012 yaitu sarana pembuangan air limbah yang tidak memenuhi syarat yaitu 65,9\%, artinya sebagian besar responden memiliki masalah dalam pembuangan air limbah. ${ }^{13}$ Penelitian Hamzah di Kecamatan Belawa, Kabupaten Wajo pada tahun 2012 juga menjelaskan bahwa pengelolaan air limbah yang tidak memenuhi syarat adalah $79(58,1 \%)$ sedangkan yang memenuhi syarat $41,9 \%$ dari 136 responden yang diteliti. ${ }^{16}$

Berdasarkan hasil wawancara dan observasi didapatkan hasil lebih dari setengah responden, pengelolaan sampah rumah tangga dapat dikatakan buruk yaitu 36 (57,1\%). Pengelolaan sampah tersebut meliputi mulai dari pengumpulan sampai pengelolaan sampah yang sudah terkumpul. Pada umumnya, responden melakukan pengelolaan sampah yang baik yaitu dengan cara dibakar dan ada juga yang ditimbun, namun sebagian responden di wilayah kerja Puskesmas Kambang memiliki kebiasaan membuang sampah sembarangan dengan sampah yang berserakan di halaman maupun belakang rumah dan tidak dikelola dengan baik. Penelitian ini sejalan dengan penelitian Aprina tahun 2013 di Kelurahan 
Terjun, Kecamatan Medan Marelan yaitu metode pemusnahan sampah yang baik adalah 25 (83,30\%), sedangkan yang tidak baik $5(16,7 \%){ }^{17}$

Berdasarkan hasil kuesioner 43,4\% memiliki tempat penampungan sampah sementara berupa wadah plastik dengan konstruksi yang tidak kuat dan mudah bocor. Beberapa tempat sampah menjadi reservoir vektor atau tempat berkembangbiaknya vektor akibat tempat sampah yang berbau. Hasil penelitian menunjukkan $32,1 \%$ mempunyai kondisi tempat sampah yang buruk dengan terdapatnya vektor. Penelitian ini sejalan dengan Octorina tahun 2012 bahwa $85(96,6 \%)$ responden yang diteliti mempunyai sarana pembuangan sampah yang tidak memenuhi syarat. ${ }^{13}$ Dalam memenuhi pengelolaan sampah yang baik, maka setiap rumah harus menyediakan tempatpenampungan sampah sementara dengan konstruksi yang memenuhi syarat (kuat dan tidak mudah bocor) dan tempat sampah harus dibersihkan setiap hari agar vektor atau lalat tidak hinggap pada tempat sampah.

3. Hubungan Faktor Lingkungan dengan Kejadian Diare Balita

Ada hubungan yang signifikan antara pembuangan tinja dengan kejadian diare balita di wilayah kerja Puskesmas Kambang Kecamatan Lengayang, Kabupaten Pesisir Selatan tahun 2013 dengan $p=0,010(p<0,05)$. Pembuangan tinja yang tidak sehat tersebut memiliki risiko 4,5 kali untuk kejadian diare balita dibandingkan responden dengan pembuangan tinja yang sehat.

Tinja yang dibuang sembarangan merupakan faktor risiko diare pada balita saat berkontak langsung dengan tangan ketika anak bermain tanah di halaman maupun di belakang rumah atau secara tidak langsung melalui vektor seperti lalat yang hinggap pada tinja dan ditularkan lewat makanan. Berdasarkan penelitian Shintamurniwaty 2006, keluarga yang memiliki frekuensi tinggi memanfaatkan jamban keluarga merupakan faktor protektif terhadap kejadian diare balita. ${ }^{18}$ Menurut penelitian Regassa et al pada tahun 2008 menyatakan bahwa ada hubungan yang signifikan dengan ketersediaan dan kepemilikan jamban dengan kejadian diare balita. ${ }^{19}$ Hasil penelitian ini juga sejalan dengan penelitian Amaliah tahun 2010 yang menyimpulkan ada hubungan yang bermakna antara ketersediaan jamban dengan kejadian diare balita dengan $p=0,017(p<0,05) .^{20}$

Pembuangan tinja yang sembarangan akan menimbulkan penyebaran penyakit yang multi kompleks. Penyebaran penyakit yang bersumber dari feses dapat melalui berbagai macam jalan dan cara baik melalui air, tangan, lalat maupun tanah yang terkontaminasi oleh tinja dan ditularkan lewat makanan dan minuman secara langsung atau melalui vektor serangga (lalat, kecoa). Masalah pembuangan kotoran manusia ini harus diatasi sedini mungkin. Kurangnya perhatian terhadap pengelolaan tinja disertai dengan cepatnya pertambahan penduduk akan mempercepat penyebaran penyakit yang ditularkan melalui tinja seperti diare yang merupakan salah satu penyakit menular yang berbasis lingkungan sebagai faktor risiko penyakit diare balita. ${ }^{1}$

Uji chi-square mendapatkan ada hubungan yang signifikan antara sumber air minum dengan kejadian diare balita di wilayah kerja Puskesmas Kambang Kecamatan Lengayang Kabupaten Pesisir Selatan tahun 2013 dengan $p=0,026(p<0,05)$.Jarak sumur dari sumber pencemaran seperti tempat pembuangan air limbah RT, tempat pembuangan sampah dan kandang ternak yang kurang dari 10 meter bermungkinan besar untuk terkontaminasi air kotor yang mengakibatkan sumber air tercemar dan tidak higiene sehingga dapat mempengaruhi terhadap kualitas air secara fisik maupun mikrobiologis. Berbagai bibit atau kuman penyakit yang dapat hidup di sumber air minum menjadi salah satu penyebab diare balita di wilayah kerja Puskesmas Kambang. Beberapa sumur yang digunakan tidak terlindung dengan kondisi sumur yang tidak memiliki cincin sehingga kemungkinan risiko untuk terkontaminasi oleh agen atau bibit penyakit dari sumber pencemaran lebih besar.

Sejalan dengan penelitian Novytania tahun 2013 yaitu ada hubungan antara sumber air dengan kejadian diare. Sumber air yang tercemar memiliki risiko tinggi terhadap kejadian diare dengan nilai signifikansi 0,006 $(p<0,05) .{ }^{15}$ Hasil penelitian Umiati juga menunjukkan ada hubungan yang bermakna antara sumber air minum yang dikonsumsi dengan kejadian diare balita di wilayah kerja Puskesmas Nogosari Kabupaten Boyolali tahun 2009 dengan $p=0,001(p<0,05)^{14}$. 
Uji chi-square juga mendapatkan ada hubungan yang signifikan antara saluran pembuangan air limbah RT dengan kejadian diare balita di wilayah kerja Puskesmas Kambang Kecamatan Lengayang Kabupaten Pesisir Selatan tahun 2013 dengan $p=$ $0,003(p<0,05)$. Saluran pembuangan air limbah yang buruk ini mempunyai risiko 6 kali mengalami kejadian diare pada balita dibandingkan responden dengan saluran pembuangan air limbah RT yang baik. Saluran pembuangan air limbah RT buruk mengakibatkan diare balita 29 (72,5\%). Penelitian ini dapat membuktikan ada hubungan saluran pembuangan airlimbah RT dengan kejadian diare balita. Hamzah juga menyatakan ada hubungan pengelolaan air limbah dengan kejadian diare balita dengan $(p=0,000) .{ }^{16}$ Penelitian ini tidak sejalan dengan penelitian Octorina di Desa Sialang Buah Kecamatan Teluk Mengkudu Kabupaten Serdang Bedagai tahun 2012 yaitu tidak ada hubungan yang signifikan antara sarana pembuangan air limbah dengan kejadian diare. ${ }^{13}$ Hasil penelitian yang berbeda juga didapatkan dari Angeline tahun 2012 di Kelurahan Sukaraja Kecamatan Medan Maimun yang menunjukkan tidak ada hubungan sarana pembuangan air limbah dengan keluhan diare $(p=0,05)$. Akan tetapi, dihitung menurut hasil perhitungan dengan $p \leq 0,05$, hasil penelitian Angeline dapat dikatakan bermakna meskipun nilai $p$ pada ambang batas. ${ }^{21}$

Berdasarkan hasil penelitian yang dilakukan dengan menggunakan uji chi-square didapatkan $p=$ 0,043 ( $p<0,05$ ). Hasil tersebut menunjukkan bahwa ada hubungan yang signifikan antara pengelolaan sampah dengan kejadian diare balita di wilayah kerja Puskesmas Kambang, Kecamatan Lengayang, Kabupaten Pesisir Selatan tahun 2013. Nilai odds ratio menunjukkan bahwa responden dengan pengelolaan sampah buruk mempunyai risiko 3,3 kali menderita diare pada balita dibandingkan responden dengan pengelolaan sampah yang baik.

Pengelolaan sampah yang baik sangat penting untuk mencegah penularan penyakit dengan cara menyediakan tempat sampah. ${ }^{10}$ Sampah harus dikumpulkan setiap hari dan dibuang ke tempat penampungan sementara. Pengelolaan sampah yang buruk juga dipengaruhi kondisi tempat penampungan sampah sementara, kebiasaan membuang sampah dan pengelolaan sampah yang sudah terkumpul. Hasil penelitian menunjukkan sebagian besar responden melakukan pengelolaan sampah dengan baik yaitu dengan cara dibakar dan sebagian ada juga yang ditimbun. Beberapa responden masih ada yang membuang sampah sembarangan seperti di belakang maupun di halaman rumah yang tidak dikelola dengan baik. Kebiasaan membuang sampah tidak pada tempatnya juga menjadi faktor risiko untuk timbulnya berbagai vektor bibit penyakit. Faktor risiko lain penyebab diare balita adalah tempat sampah yang digunakan dengan konstruksi yang tidak kuat dan mudah bocor seperti wadah plastik dan kantong plastik dan beberapa kondisi tempat sampah terdapat vektor seperti serangga yang dapat menyebabkan diare pada balita.

Penelitian ini sejalan dengan penelitian Regassa et al bahwa ada hubungan yang signifikan antara pembuangan sampah dengan kejadian diare pada anak di bawah 5 tahun. ${ }^{19}$ Akan tetapi, hasil penelitian yang berbeda didapatkan oleh Octorina yang menunjukkan tidak ada hubungan sarana pembuangan sampah di Desa Sialang Buah, Kecamatan Teluk Mengkudu, Kabupaten Serdang Bedagai dengan kejadian diare dengan $p=1,000(p>0,05) .^{13}$

\section{KESIMPULAN}

Kejadian diare balita di wilayah kerja Puskesmas Kambang Kecamatan Lengayang Kabupaten Pesisir Selatan tahun 2013 adalah 57,1\%.

Pembuangan tinja yang tidak sehat di wilayah kerja Puskesmas Kambang Kecamatan Lengayang Kabupaten Pesisir Selatan tahun 2013 lebih banyak dibandingkan pembuangan tinja yang tidak sehat.

Sumber air minum yang sehat di wilayah kerja Puskesmas Kambang Kecamatan Lengayang Kabupaten Pesisir Selatan tahun 2013 lebih banyak dibandingkan sumber air minum yang tidak sehat.

Saluran pembuangan air limbah rumah tangga yang buruk di wilayah kerja Puskesmas Kambang Kecamatan Lengayang Kabupaten Pesisir Selatan tahun 2013 lebih banyak dibandingkan saluran pembuangan air limbah yang baik.

Pengelolaan sampah yang buruk di wilayah kerja Puskesmas Kambang Kecamatan Lengayang Kabupaten Pesisir Selatan tahun 2013 lebih banyak dibandingkan dengan pengelolaan sampah baik. 
Terdapat hubungan yang signifikan antara pembuangan tinja, sumber air minum, saluran pembuangan air limbah rumah tangga, pengelolaan sampah, dengan kejadian diare balita di wilayah kerja Puskesmas Kambang Kecamatan Lengayang Kabupaten Pesisir Selatan tahun 2013.

\section{UCAPAN TERIMA KASIH}

Penelitian ini dapat berlangsung berkat dukungan dari para pembimbing yaitu Prof. Dr. dr. Rizanda Machmud, M.Kes dan dr. Roslaili Rasyid, M. Biomed. Terima kasih atas bimbingan, arahan dan motivasi yang diberikan.

\section{DAFTAR PUSTAKA}

1. Notoatmodjo S. Prinsip-prinsip dasar IImu Kesehatan Masyarakat, Jakarta: Rineka Cipta; 2003.

2. World Health Organization. Diarrhoeal Disease. 2013 (diunduh 30 September 2013). Tersedia dari: URL: HYPERLINK http://www.who.int/mediacentre/ factsheets/fs330/en/index.html.

3. Kementrian Kesehatan RI. Situasi diare di Indonesia. Buletin Jendela: Data dan Informasi Kesehatan. 2011;2: 1-38.

4. Dinas Kesehatan Provinsi Sumatera Barat. Laporan diare dinas kesehatan provinsi Sumatera Barat tahun 2012. Padang: 2013.

5. Dinas Kesehatan Kabupaten Pesisir Selatan. Kasus Diare yang ditangani menurut jenis kelamin, Kecamatan, dan Puskesmas Kabupaten Pesisir Selatan tahun 2012. Pesisir Selatan : Bidang P2B \& PL. 2013.

6. UNICEF, World Health Organization. Diarhoea. Why children are still dying and what can be done (diunduh 22 Oktober 2013). Tersedia dari: URL: HYPERLINK http://whqlibdoc.who.int/publications/ 2009/9789241598415eng.pdf; 2009.

7. Kementerian Kesehatan RI. Riset kesehatan dasar (Riskesdas). Jakarta: Badan Penelitian dan Pengembangan Kesehatan; 2007.

8. Depkes RI. Pedoman pemberantasan penyakit diare. Jakarta : Ditjen PPM \& PL. 2003: 10.

9. Widoyono. Penyakit tropis: epidemiologi, penularan, pencegahan dan pemberantasannya. Jakarta: Erlangga; 2008.
10. Depkes RI. Buku pedoman pengendalian penyakit diare. Jakarta: Ditjen PP \& PL; 2009.

11. Puskesmas Kambang. Laporan Tahunan Puskesmas Kambang Tahun 2012; 2013.

12. Sastroasmoro S, Sofyan I. Dasar-Dasar Metodologi Penelitian Klinis, Edisi ke-4. Jakarta : CV Sagung Seto; 2011.

13. Octorina F, Dharma S, Marsaulina I. Hubungan kondisi lingkungan perumahan dengan kejadian diare di desa Sialang Buah Kecamatan Teluk Mengkudu Kabupaten serdang Bedagai Tahun 2012. Medan: FKM Universitas Sumatera Utara; 2012.

14. Umiati. Hubungan antara sanitasi lingkungan dengan kejadian diare pada balita di wilayah kerja Puskesmas Nogosari Kabupaten Boyolali tahun 2009 (skripsi). Program Studi Kesehatan Masyarakat, Fakultas IImu Kesehatan, Universitas Muhammadiyah Surakarta; 2010.

15. Novytania W, Chuluq C, Sudiarto. Hubungan faktor lingkungan dengan faktor sosiodemografi terhadap kejadian diare di Kecamatan Kabuh Kabupaten Jombang. Fakultas Kedokteran Universitas Brawijaya; 2013.

16. Hamzah B, Arsin A, Ansar J. Hubungan perilaku hidup bersih dan sehat dengan kejadian diare pada balita di Kecamatan Belawa Kabupaten Wajo tahun 2012. Makassar: FKM UNHAS; 2012.

17. Aprina M. Hubungan kualitas mikrobiologis air sumur gali dan pengelolaan sampah di rumah tangga dengan kejadian diare pada keluarga di kelurahan Terjun Kecamatan Medan Marelan Tahun 2013 (skripsi). Medan: FKM Universitas Sumatera Utara; 2013.

18. Sinthamurniwaty. Faktor-faktor risiko kejadian diare akut pada balita (studi kasus di Kabupaten Semarang) (tesis). Semarang: Universitas Diponegoro; 2006.

19. Regassa G, Birke W, Deboch B, Belachew T. Evironmenthal determinants of diarrhea among under five children in Nekemte Town, Western Ethiopia. Ethiop J Health Sci. 2008;18(2): 39-45.

20. Amaliah S. Hubungan sanitasi lingkungan dan faktor budaya dengan kejadian diare pada anak balita di desa Toriyo Kecamatan Bendosari Kabupaten Sukoharjo. Semarang: Prosiding 
Seminar Nasional Universitas Muhammadiyah Semarang; 2010.

21. Angeline YL, Marsaulina I, Naria E. Hubungan kondisi sanitasi dasar dengan keluhan kesehatan diare serta kualitas air pada pengguna air sungai

Deli di kelurahan Sukaraja Kecamatan Medan

Maimun Tahun 2012. Medan: FKM USU; 2012. 